EL DINAR: Jurnal Keuangan dan Perbankan Syariah

Volume 7 , No. 1, Tahun 2019

P ISSN: 2339-2797; E ISSN: 2622-0083

\title{
PROFITABILITY AND LEVERAGE, AND THE IMPLICATION ON THE DIVIDEND POLICY OF JAKARTA ISLAMIC INDEX
}

\author{
Anaz Bima Dewantara \\ Faculty of Economics, Universitas Islam Negeri Maulana Malik Ibrahim Malang \\ anazbima@gmail.com \\ Siswanto \\ Faculty of Economics, Universitas Islam Negeri Maulana Malik Ibrahim Malang \\ siswanto@pbs.uin-malang.ac.id \\ Achmad Maulana Rizqi \\ Faculty of Economics, Universitas Islam Negeri Maulana Malik Ibrahim Malang ${ }^{2}$ \\ achmadmaulanarizqii@gmail.com
}

\section{Abstrak}

Tujuan penelitian ini adalah untuk menganalisis pengaruh leverage dan profitabilitas terhadap kebijakan dividen yang diperkuat oleh likuiditas dan kecukupan kas. Likuiditas dan kecukupan kas diasumsikan sebagai variabel moderasi. Penelitian ini menggunakan analisis regresi dengan variabel moderasi. data panelitian menggunakan laporan keuangan perusahaan yang terdaftar di Jakarta Islamic Index pada periode 20122016. Hasil penelitian menunjukkan profitabilitas dan leverage tidak berpengaruh terhadap kebijakan dividen. Adapun, likuiditas tidak dapat memoderasi profitabilitas dan leverage untuk kebijakan dividen. Oleh karena itu, variabel kas dan variabel setara kas dapat memoderasi hubungan antara ROA dan kebijakan dividen, tetapi mereka tidak dapat memoderasi kebijakan ROE, DER, dan DAR untuk dividen.

Kata Kunci: Leverage, profitabilitas, kebijakan deviden, Jakarta Islamic Index

\section{Abstract}

The aim of this study is to analyze the influence of leverage and profitability to dividend policy reinforced by liquidity and cash adequacy. Liquidity and cash sufficiency was assumed as moderation variable. This research used moderated regression analysis. Data obtained from secondary data that is company's financial report registered at Jakarta Islamic Index in period 2012-2016. The results show that profitability and leverage had no effect on dividend policy. Otherwise, liquidity is not able to moderate profitability and leverage to dividend policy. Therefore, cash 
Anaz Bima Dewantara: Profitability and leverage, and the Implication

variable and cash equivalents variable are able to moderate the relationship between ROA and dividend policy, but those can't moderate $\mathrm{ROE}, \mathrm{DER}$, and DAR to dividend policy.

Keywords: Leverage, profitability, dividend policy, Jakarta Islamic Index

\section{INTRODUCTION}

Investment development goes rapidly from year-to-year in Indonesia. It is proved by more companies participating in the stock exchange during 2017. The numbers of companies that made offers of initial public offering (IPO) were sharply increased in 2017, that more than 30 companies would do IPO (Komalasari, 2017). The investment growth in Islamic stock market is more dominant from non-Islamic until the end of 2015. Total products of Islamic stocks registered 318 stocks or $61 \%$ of the total Indonesian stock market capitalization. However, the total Islamic stocks during 2015 increased by 34\% to 318 stocks since Indeks Saham Syariah Indonesia (ISSI) or Indonesian Islamic Stock Index published in 2011. At that time, Islamic stock comprised on 237 stocks (Setiawan, 2016). Based on this data, Islamic stocks are projected to be able to provide benefits.

One of the benefits gained by the investors is dividend sharing. Dividend sharing is one way to improve the welfare of stockholders (Gunawan, 2015). Therefore, dividend policies will get the major attention from the investors. The determinants of dividend sharing are determined by some factors, namely: solvability position, liquidity position, needs to pay debts, plan to develop the investment opportunities, income stability, and monitoring to companies (Sutrisno, 2012). However, Brigham and Houston (2001) stated that dividend sharing has to consider cash supply.

Profitability affects dividend policies. Devi and Suardhika (2014) showed the profitability level (ROA) affects dividend sharing on companies. Pasadena (2013) also showed profitability variables that have a positive effect on Dividend payout ratio (DPR). Ayu (2013) showed that ROA variables affect dividend policies. Idawati and Sudiarta (2011) stated that dividend policies are affected by profitability. However, Permana (2016) and Ulfah (2013) stated that profitability (ROA) does not affect the dividend policies. ROE affects the dividend 
Anaz Bima Dewantara: Profitability and leverage, and the Implication

policies. Profitability proxied by ROE variables affects the dividend policies (Rahayu \& Hari, 2016; Susanti 2016). Whereas, other studies (Setyawan, 2014; Sarmento and Dana, 2016) showed that ROE does not affect the dividend policies.

The dividend policies are influenced by leverage. Leverage is proxied by the variable of debt to Equity Ratio (DER) and Debt to Assets Ratio (DAR). DER has a positive effect on dividend policies (Raissa, 2011). However, Saleh (2015) showed that DER has a negative effect on dividend policies. Pasadena (2013) showed that DER does not affect the dividend policies. Related to Debt to Assets Ratio (DAR) it has a research contradiction. Kardiyanah (2013) showed that DAR has a positive effect on dividend policies, while Noviyanti and Kamilah (2015) showed that DAR has a negative effect on dividend policies. Ulfah (2015) showed that DAR does not affect dividend policies.

Liquidity can enhance and weaken the dividend policies. Liquidity factor can enhance the relationship between profitability level and leverage by cash dividend policy of the companies (Hastuti, 2013:5). Happy (2016), Afifah (2015), and Haq (2014) stated that liquidity can be used as moderation variable. While, cash and cash equivalent, according to Oktoriana and Suharli (2007), can be used as moderation variable. Based on the study contradiction and the review of the literature, this study aimed to analyze the implication of profitability and leverage on dividend policies with liquidity as the moderation variables on Jakarta Islamic Index is projected to fill the relevant research opportunity. Since, there was contradiction academically and practically.

\section{THEORETICAL REVIEW AND HYPOTHESIS DEVELOPMENT Profitability and Dividend Payout Ratio}

Profitability level controls the large and small dividend sharing. Since, dividend is the part of net profit of a company. Susanti (2016) said that the success of a company is shown as the capability of the company to pay the dividends. ROA is the measurement of company effectivity in generating profits. ROA value reflects a good company performance, because of its higher investment return.

The financial performance of companies often uses Return on Equity (ROE). ROE draws the company's ability to generate profits through its own capital. Whereas, dividend is the part of net profit of the 
Anaz Bima Dewantara: Profitability and leverage, and the Implication

companies. Dividend will be shared to stockholders if the companies receive profits (Susanti, 2016). Companies that have good cash flow or profitability will be able to pay dividends or increase its dividends (Ulfah, 2011).

H1.a : ROA affects dividend policies (DPR)

H1.b : ROE affects dividen policies (DPR)

\section{Leverage and Dividend Payout Ratio}

According to Riyanto (2007) in Saleh (2015:5), DER reflects the company's capability to meet all its obligations shown by some parts of its capital used to pay off its debts. The greater ratios show the bigger obligations of the company and the lower ratio will show higher the capability of the company to meet its obligation. If the company decides to pay off all its debts by using retained earning, it means that the company has to retain most of its income to meet the requirement, meaning that only small parts of its income will be paid for dividend

While, according to Ulfah (2015:4), Debt to Assets Ratio (DAR) is one of ratio used to draw how much assets of the company financed by the debts. The source of fund came from debts will be the most priority of the obligations. The more debts belonged to the company, the total obligations will be bigger, thus the available profit of the company to its stockholders will be decreased.

H2.a : DER affects dividend policies (DPR)

H2.b : DAR affects dividend policies (DPR)

\section{Liquidity as a Moderating Variable}

Liquidity is the capability of companies to pay off their short obligations, such as paying debts or paying dividends. Dividends will be paid more if the level of company liquidity is higher because dividends are outflow cash. Affordable cash is certainly not owned by companies with high profits so that if companies want to distribute dividends, companies need to have sufficient cash because dividends are generally distributed in the form of cash dividends (Devi \& Suardikha, 2014).

In addition, in previous studies, Happy (2016), Afifah (2015), and Haq (2014) said that liquidity can be used as a moderating variable. Whereas in the research of Nugaraha and Mertha (2016) said that 
Anaz Bima Dewantara: Profitability and leverage, and the Implication

liquidity cannot be used as a moderating variable. Based on the explanation above, the writer proposed the research hypothesis as follows:

H3.a: Liquidity (CR) can strengthen the relationship between profitability (ROA and ROE) and dividend policies (DPR)

H3.b: Liquidity (CR) can strengthen the relationship between leverage (DER and DAR) and dividend policies (DPR)

\section{Cash and Cash Equivalents as Moderator Variables}

Oktoriana \& Suharli (2007) say that if a company has an independent cash flow, usually the company's manager gets pressure from shareholders to distribute dividends. The greater the independent cash flow paid to shareholders indicates the magnitude of the manager's attention as an agent of shareholders in the company. Dividends reflect current cash flows and future cash flows. Only companies that have current cash adequacy are able to pay cash dividends at this time. Thus the hypothesis that can be proposed is:

H4.a: Cash and Cash Equivalents can strengthen the relationship between profitability (ROA and ROE) and dividend policies (DPR)

H4.b: Cash and Cash Equivalents can strengthen the relationship between profitability (DER and DAR) and dividend policies (DPR)

\section{METHOD}

The variables used in this study are profitability variables measured by ROA and ROE, Leverage measured by DER and DAR as independent variables, Liquidity (CR) and Cash Adequacy (Cash and Cash Equivalents) as moderating variables, and Dividend Payout Ratio as dependent variables. The method used in this research is explanatory research method. Sample population, the population used in this study are stocks listed in the Jakarta Islamic Index in the period of 2012 to 2016. The sample in this study was taken by purposive sampling, where the sample used must meet the following criteria: a) on research period, b) the company is consistently listed on JII during the observation period, c) presenting financial statements, d) presenting financial ratios used in the study. Data collection, data collection techniques used in this study are through the documentation method. Variable operational definition is below: 


\begin{tabular}{|c|c|c|c|}
\hline No & Concept & Variable & Measurement \\
\hline 1 & Profitability & $\begin{array}{l}\text { Return on Aset } \\
\left(\mathrm{X}_{1}\right)\end{array}$ & $R O A=\frac{(\text { EAIT })}{\text { Total Asset }}$ \\
\hline 2 & Profitability & $\begin{array}{l}\text { Return on } \\
\text { Equity }\left(\mathrm{X}_{2}\right)\end{array}$ & $R O E=\frac{(E A I T)}{\text { Total Equity }}$ \\
\hline 3 & Leverage & $\begin{array}{l}\text { Debt to Equity } \\
\text { Ratio }\left(\mathrm{X}_{3}\right)\end{array}$ & $D E R=\frac{\text { Total Liabilities }}{\text { Total Assets }}$ \\
\hline 4 & Leverage & $\begin{array}{l}\text { Debt to Aset } \\
\text { Ratio }\left(\mathrm{X}_{4}\right)\end{array}$ & $D A R=\frac{\text { Total Liabilities }}{\text { Total Equity }}$ \\
\hline 5 & Dividend Policies & $\begin{array}{l}\text { Dividend } \\
\text { payoutratio }(\mathrm{Y})\end{array}$ & Dividend Payout Rasio $=\frac{\text { Deviden Pershare }}{\text { Earning Pershore }}$ \\
\hline 6 & Liquidity & $\begin{array}{l}\text { Current Ratio } \\
\left(\mathrm{M}_{1}\right)\end{array}$ & Current Ratio $=\frac{\text { Current Assets }}{\text { Current Liabilities }}$ \\
\hline 7 & Cash Adequacy & $\operatorname{Cash}\left(\mathrm{M}_{2}\right)$ & Cash and Cash Equivalents \\
\hline
\end{tabular}

The analytical tool used in Moderated Regression Analysis (MRA), an analytical technique that emphasizes an analytical approach that maintains sample integrity and provides a basis for controlling the influence of moderator variables. The structural equation for this research is:

$Y=\alpha+\beta_{1} X_{1}+\beta_{2} X_{2}+\beta_{3} X_{3}+\beta_{4} X_{4}+\beta_{5} M_{1}+\beta_{6} M_{2}+\beta_{7} X_{1} \cdot M_{1}+\beta_{8} X_{2} \cdot M_{1}+\beta_{9} X_{1} \cdot M_{2}$

$+\beta_{10} X_{2} \cdot M_{2}+\beta_{11} X_{3} \cdot M_{1}+\beta_{12} X_{4} \cdot M_{1}+\beta_{13} X_{3} \cdot M_{2}+\beta_{14} X_{4} \cdot M_{2}+e$

\section{RESULT AND DISCUSSION}

Normality Test was conducted in this study with one sample Kolmogorov-Smirnov testing using SPSS software from one sample Kolmogorov-Smirnov of 0.259 greater than $\alpha(0.05)$. Based on the three tests, which means that the residual distribution is normally distributed (assumptions fulfilled). The Heteroscedasticity test in this study uses a scatter plot test wherein the results of the test see randomly scattered (not patterned) points both above and below the number 0 on the Y-axis, which means that the assumption of heteroscedasticity is fulfilled 
Anaz Bima Dewantara: Profitability and leverage, and the Implication

(homogeneous residual variety). Auto Correlation Test where this study uses the Durbin Watson test, the value of Durbin Watson 2.256 is more than the value of two things, proving that there is no problem of autocorrelation. Multicollinearity test, based on the results of multicollinearity test results showed that the regression equation experienced the results of multicollinearity this is because the tolerance value is more than 1 and the VIF value is more than 10 . This is because there is a strong interaction between the independent variable and the moderator variable. This often occurs in the MRA test and the absolute difference value. Therefore the researcher also uses a residual value test to ensure the results of the moderating variable when there is no multicollinearity and the results show that all variables have a significant value of more than 0.05 . The result of sample test on listed stocks in JII can be seen in the table below:

Table 2 MRA Test Result

\begin{tabular}{lcccc}
\hline \multirow{2}{*}{ Variable } & B & arithmetic & Significance & decisions \\
\cline { 2 - 5 } Constant & 39.381 & - & - & - \\
X1 (ROA) & 0.092 & 0.035 & 0.972 & no significant \\
X2 (ROE) & -0.024 & -0.020 & 0.984 & no significant \\
X3 (DER) & 0.153 & 0.254 & 0.801 & no significant \\
X4 (DAR) & -0.002 & -0.001 & 0.999 & no significant \\
M1 (CR) & -0.146 & -1.034 & 0.306 & no significant \\
M2 & $-8.712 \times 10^{-7}$ & -0.182 & 0.856 & no significant \\
X1.M1 & 0.024 & 1.376 & 0.174 & no significant \\
X2.M1 & -0.009 & -0.894 & 0.375 & no significant \\
X3.M1 & 0.003 & 1.171 & 0.247 & no significant \\
X4.M1 & -0.006 & -1.225 & 0.226 & no significant \\
X1.M2 & $-5.158 \times 10^{-7}$ & -2.527 & 0.014 & significant \\
X2.M2 & $2.091 \times 10^{-7}$ & 1.941 & 0.057 & no significant \\
X3.M2 & $-1.738 \times 10^{-7}$ & -1.947 & 0.057 & no significant \\
X4.M2 & $3.713 \times 10^{-7}$ & 1.416 & 0.162 & no significant \\
R2 & & $=0.439$ & & \\
Farithmetic & & $=3.078$ & & \\
F-table (F14,55,0.05) & $=1.876$ & & \\
Significance of F arithmetic & $=0.001$ & & \\
t-table (t55,0.05) & & $=2.004$ & & \\
Error standard & & $=22.819$ & & \\
\hline
\end{tabular}


With sub-structural equation:

$\mathrm{Y}=41,891+1.375 \mathrm{X} 1-0.024 \mathrm{X} 2+0.153 \mathrm{X} 3-0.002 \mathrm{X} 4-0.146 \mathrm{M} 1-$ $8.712 \times 10^{-7} \mathrm{M} 2+0.024 \mathrm{X} 1 . \mathrm{M} 1-0.009 \mathrm{X} 2 . \mathrm{M} 1+0.003 \mathrm{X} 3 . \mathrm{M} 1-0.006$ $\mathrm{X} 4 . \mathrm{M} 1-5.158 \times 10^{-7} \mathrm{X} 1 . \mathrm{M} 2+2.091 \times 10^{-7} \mathrm{X} 2 . \mathrm{M} 2-1.738 \times 10^{-7} \mathrm{X} 3 . \mathrm{M} 2+$ $3.713 \times 10^{-7} \mathrm{X} 4 . \mathrm{M} 2+22.819$

Those variables of X1 (ROA), X2 (ROE), X3 (DER), X4 (DAR), M1 (CR), M2 (cash and cash equivalents), and the interaction between each independent variables and each moderation variables have significant effect simultaneously to $\mathrm{Y}$ variable (DPR). It can be seen on $\mathrm{F}$ arithmetic value that greater than $F_{\text {table }}(3.078>1.876)$, or from a significant value less than $\alpha(0.001<0.05)$. The regression equation that explains the effect of X1 (ROA), X2 (ROE), X3 (DER), X4 (DAR), M1 (CR), M2 (cash and cash equation), and interaction between each independent variables and each moderation variables to Y (DPR). Based on table 4.16, it is known that $R$ Square value on equation 3 is 0.439 or $43.9 \%$. It means that DPR variable $(\mathrm{Y})$ is explained at $43.9 \%$ by all independent variables plus moderation variables as independent variables and the interaction between independent variables and moderation variables. Whereas the residual at $56.1 \%$ is explained by variables/other factors outside the regression equation. Variable $\mathrm{X} 1$ (ROA) has no significant effect on variable $Y$ (DPR). It can be seen from the value of $t$ arithmetic less than $t$ table $(0.035<2,004)$, or from a significance value greater than $\alpha(0.972>$ 0.050 ). The variable $X 2$ (ROE) has no significant effect on variable $Y$ (DPR). It can be seen from the $t$ arithmetic less than $t$ table $(0.020<2,004)$, or from a significance value greater than $\alpha(0.984>0.050)$. The $\mathrm{X} 3$ variable (DER) has no significant effect on the $Y$ variable (DPR). It can be seen from the $t$ arithmetic less than $t$ table $(0.254<2,004)$, or from a significance value greater than $\alpha(0.801>0.050)$.

Variable X4 (DAR) has no significant effect on variable Y (DPR). It can be seen from the value of $t$ arithmetic less than $t$ table $(0.001<2,004)$, or from a significance value greater than $\alpha(0.999>0.050)$. The variable M1 (CR) has no significant effect on the Y variable (DPR). It can be seen from the $t$-arithmetic less than $t$ table $(1,034<2,004)$, or from the significance value greater than $\alpha(0.306>0.05)$. M2 variables (cash and cash equivalents) have no significant effect on the Y variable (DPR). It can be seen from the $\mathrm{t}$ arithmetic less than $\mathrm{t}$ table $(0.182<2,004)$, or from a significance value 
Anaz Bima Dewantara: Profitability and leverage, and the Implication

greater than $\alpha(0.856>0.05)$. Variable X1 (ROA) with variable M1 (CR) as moderating variables have no significant effect on variable Y (DPR). It can be seen from the value of $t$ arithmetic less than $t$ table $(1.376<2.004)$, or from a significance value greater than $\alpha(0.174>0.050)$. The variable M1 (CR) does not moderate the effect of variable X1 (ROA) on Y (DPR) because of the insignificant interaction effect.

Variable M1 (CR) does not moderate the effect of variable X1 (ROA) on Y (DPR) because of the insignificant interaction effect. Variable X2 (ROW) with variable M1 (CR) as moderation variables have no significant effects on variable Y (DPR). It can be seen from $t$ arithmetic value less than $t$ table $(0.894<2.004)$, or from significance value greater than $\alpha$ $(0.375>0.050)$. Variable M1 (CR) does not moderate the effect of variable X2 (ROA) on Y (DPR) because of the insignificant interaction effect. Variable X3 (DER) with variable M1 (CR) as moderation variables have no significant effects on variable $Y$ (DPR). It can be seen from $t$ arithmetic value less than $t$ table $(1.171<2.004)$, or from significance value greater than $\alpha(0.247>0.050)$. Variable M1 (CR) does not moderate the effect of variable X3 (DER) on Y (DPR) because of the insignificant interaction effect. Variable X4 (DAR) with variable M1 (CR) as moderation variables have no significant effect on variable $Y$ (DPR). It can be seen from $t$ arithmetic value less than $t$ table $(1.225<2.004)$, or from significance value greater than $\alpha(0.226>0.050)$. Variable M1 (CR) does not moderate the effect of variable X4 (DAR) on Y (DPR) because of the insignificant interaction effect.

Variable X1 (ROA) with variable M2 (cash and cash equivalents) as moderation variables have significant effects on variable Y (DPR). It can be seen from $t$ arithmetic value greater than $t$ table $(2.527>2.004)$, or from significance value less than $\alpha(0.014<0.050)$. Variable M2 (cash and cash equivalents) moderates the effect of variable X1 (ROA) on Y (DPR) with a significant interaction effect. Negative regression coefficient explains that if there is an increase of $5.158 \times 10^{-7}$ variable $\mathrm{X} 1$ (ROA) with variable M2 (cash and cash equivalents) as moderation variables will decrease variable Y (DPR) of $5.158 \times 10^{-7}$ significantly, or in the other word, moderation variable M2 weakens the effect of $\mathrm{X} 1$ on $\mathrm{Y}$ because it changes the effect into negative.

Variable X2 (ROE) with variable M2 (cash and cash equivalent) as moderation variables affect insignificantly on variable Y (DPR). It can be 
Anaz Bima Dewantara: Profitability and leverage, and the Implication

seen from $t$ arithmetic value less than $t$ table $(1.941<2.004)$, or from significance value greater than $\alpha(0.057>0.050)$. Variable M2 (cash and cash equivalents) does not moderate the effect of variable X2 (ROE) on Y (DPR) because of the insignificant interaction effect. Variable X3 (DER) with variable M2 (cash and cash equivalents) as moderation variables affect insignificantly on variable $\mathrm{Y}$ (DPR). It can be seen from $t$ arithmetic value less than $t$ table $(1.947<2.004)$, or from significance value greater than $\alpha(0.057>0.050)$. Variable M2 (cash and cash equivalents) does not moderate the effect of variable X3 (DER) on Y (DPR) because of the insignificant interaction effect. Variable X4 (DAR) with variable M2 (cash and cash equivalents) as moderation variables affect insignificantly on variable $Y$ (DPR). It can be seen from $t$ arithmetic value less than $t$ table $(1.416<2.004)$, or from significance value greater than $\alpha(0.162>$ 0.050). Variable M2 (cash and cash equivalent) does not moderate the effect of variable X4 (DAR) on Y (DPR) because of the insignificant interaction effect.

\section{DISCUSSION}

\section{Profitability on Dividend Policies}

It can be concluded that ROA and ROE have insignificant effects, meaning that growth or reduction of profitability will not affect on the increase of dividend sharing in the companies. Permana (2016) stated that profitability belonged by companies cannot guarantee that the companies will pay more dividends to the investors. In the condition of low profitability, the companies will pay off dividends. They aim to preserve their reputations among capital market actors. In the condition of high profitability, companies will share out the low dividends (Jensen, Solberg and Zom, 1992 in Nidya \& Titik, 2015). It occurs because the companies share some profits out as the internal fund source. In this way, the internal fund source will be increased. Thus the companies can postpone the strategy to use debts or new stock emission. Besides, in 2013-2015 there was a reduction in Rupiah exchange value, so the companies had to provide more funds to cover this condition.

\section{Leverage on Dividend Policies}

Based on the test result, it can be concluded that DER and DAR have insignificant effects, meaning that the growth or reduction of 
Anaz Bima Dewantara: Profitability and leverage, and the Implication

leverage will not affect on the increase of dividend sharing. Companies that have capital structures consisting of creditors and stockholders, wherein management does not consider only to the interest of debt holders for obligations payment, but also considering the interest of shareholders by paying dividends (Kristianawati, 2012:16). Besides, in the observation period, in 2014 Bank Indonesia changed the policy of interest rate from 7.5 to 7.75 and this condition increased the bank interest rates. Moreover, with controlling debts that had an interest not more than $45 \%$ in Islamic stock, the companies' debts were controlled and the investors, who wanted to make investments, would not consider to the companies' debts.

\section{Liquidity as Moderator Variable}

Based on the result of this study, it can be concluded that liquidity has an insignificant effect, meaning that it cannot be used as a moderation variable. Nugaraha and Merta (2016) stated that liquidity could not be used as a moderation variable. It shows that companies that have the high total liquidity will tend to fill their operational activities or have other considerations than share dividends to the stockholders of the companies. Nugaraha and Merta (2016) also said that investors have different points of view and they do not make the liquidity ratios as the determinant to manage debts in the companies more effective in rising high return.

\section{Cash Sufficiency as Moderating Variable}

Based on the result, the cash variable and cash equivalents can moderate the relation between profitability (ROA) and the dividend payout ratio. Oktoriana \& Suharli (2007) showed that the companies are owning more cash certainly obtain many pressures from investors to share the cash as dividends. Moreover, variables of cash and cash equivalents cannot be moderation variables, because those are not real moderator variables. In the other condition, cash and cash equivalents are rarely used by researchers in their studies. However, cash in (Ari, 2013) and (SAK, 1994) is a payment instrument that is ready and open to financing the general activities of the companies. 
Anaz Bima Dewantara: Profitability and leverage, and the Implication CONCLUSION

Based on the analysis result explained in the previous chapter, it can be concluded that: 1) profitability proxied by ROA and ROE affects insignificantly, meaning that growth or reduction of profitability will not affect the increase of dividend sharing of the companies, 2) leverage proxied by DER and DAR affects insignificantly, meaning that growth or reduction of leverage will not affect the increase of dividend sharing of the companies, 3) liquidity proxied by liquidity CR is not able to moderate the relation between profitability and leverage to dividend policies, 4) cash sufficiency proxied by cash and cash equivalents can moderate the relation between ROA and dividend policies, but it cannot moderate the relation between ROE, DER and DAR to dividend policies. Based on the result of the study, the writer can give suggestions to investors who want to get an appropriate rate of return; they should consider many aspects, not only profitability, capital structures of the company, or leverage aspects. It is because the companies in sharing dividends do not only consider the profitability and capital structure.

\section{REFERENCES}

Afifah, D. (2015). Pengaruh Profitabilitas, Growth Potential, Free Cash Flow Terhadap Cash Dividen Dengan Likuiditas Sebagai Variabel Moderasi (Studi Pada Perusahaan yang Terdaftar dalam Jakarta Islamic Index) (Skripsi). Malang: Fakultas Ekonomi UIN Maulana Malik Ibrahim.

Ari, S. (2013, November 5). Retrieved from http://satrioarie.blogspot.co.id/2013/11/kas-dan-setara-kas_4202.html

Ayu, T. K. (2013). Pengaruh Profitabilitas, Invesment Oportunity Set, Leverage, Dan Growth, Terhadap Kebijakan Dividen (Study Empiris Perusahaan Manufaktur di Bursa Efek Indonesia) (Skripsi). Surakarta: Fakultas Ekonomi dan Bisnis Universitas Muhammadiyah Surakarta.

Brigham, E. F., \& Huston, J. F. (2001). Manajemen Keuangan : Edisi Kedelapan. Jakarta: Erlangga.

Devi, A., \& Suardikha, I. (2014). Pengaruh Profitabilitas Pada Kebijakan Dividen Dengan Likuiditas Dan Kepemilikan Manajerial Sebagai Variabel Pemoderasi. Bali: E-Jurnal Ekonomi dan Bisnis Universitas Udayana.

Gunawan, E. (2015). Pengaruh Profitabilitas Dan Likuiditas Terhadap Kebijakan Dividen (Studi Empiris Pada Perusahaan Manufaktur 
Anaz Bima Dewantara: Profitability and leverage, and the Implication

Yang Terdaftar Di Bursa Efek Indonesia Periode 2009-2013) (Skripsi). Bandung: Fakultas Ekonomi Univesitas Widyagama.

Happy, M. S. (2016). Pengaruh Struktur Modal Terhadap Profitabilitas Perusahaan Dengan Likuiditas Sebagai Variabel Moderating (Studi Kasus Pada Perusahaan Yang Terdaftar Di Jakarta Islamic Index (JII) 2013-2015) (Skripsi). Semarang: Fakultas Ekonomi dan Bisnis Islam Universitas Islam Negeri Walisongo.

Haq, T. A. (2014). Pengaruh Kepemilikan Manajerial, Profitabilitas, dan Growth Terhadap Kebijakan Dividen Dengan Likuiditas Sebagai Variabel Moderating. STIE Perbanas, 1-15.

Hastuti, D. (2013). Pengaruh Profitabilitas, Dan Set Kesempatan Investasi Terhadap Kebijakan Dividen Tunai Dengan Likuiditas Sebagai Variabel Moderating Pada Perusahaan Manufaktur Di Bursa Efek Indonesia Periode 2008-2011 (Skripsi). Yogyakarta: Fakultas Ekonomi Universitas Negeri Yogyakara.

Idawati, I. A., \& Sudiartha, G. M. (2011). Pengaruh Profitabilitas, Likuiditas, Ukuran Perusahaan Terhadap Kebijakan Dividen Perusahan Manufaktur Di BEI. Bali: Universitas Udayana.

Isticharoh, R. R. (2016). Pengaruh Kepemilikan Manajerial, Kebijakan Hutang, dan Profitabilitas Terhadap Kebijakan Dividen . Jurnal Perbanas.

Kardianah. (2013). Pengaruh Kepemilikan Institusional, Kebijakan Hutang, Ukuran Perusahaan, Profitabilitas, dan Likuiditas Terhadap Kebijakan Dividen. Jurnal Ilmu dan Riset Manajemen, 121.

Kasmir. (2010). Analisa Laporan Keuangan . Jakarta: Rajawali Pers.

Kristianawati, I. (2012). Pengaruh Free Cash Flow, Profitabilitas, Likuiditas, dan Leverage Terhadap Kebijakan Dividen (Studi Empiris di Bursa Efek Indonesia tahun 2007-2011) . Semarang : Fakultas Ekonomi dan Bisnis Universitas Dian Nuswantoro.

Komalasari, T. D. (2017, Juni 20). Ekonomi. Retrieved September 10, 2017, from Pikiran Rakyat .com: http://www.pikiranrakyat.com/ekonomi/2017/06/20/perusahaan-ipo-meningkattajam-sepanjang-2017-403627

Nidya, A. P., \& Titik, F. (2015). Pengaruh Debt to Equity Rasio, Profitabilitas, Growth, dan Ukuran Perusahaan, Terhadap Kebijakan Dividen (Studi Pada Perusahaan Manufaktur yang Terdaftar di Bursa Efek Indonesia Periode 2010-2013). EProceeding of Management , 488-496.

Noviyanti, S., \& Kamaliah. (2015). Faktor-Faktor Yang Mempengaruhi Kebijakan Pembayaran Dividen Kas (Studi Pada Perusahaan 
Anaz Bima Dewantara: Profitability and leverage, and the Implication

Manufaktur Yang Terdaftar Di Bursa Efek Indonesia). Jurnal Tepak Manajemen Bisnis, 295-311.

Nugraha , N. A., \& Mertha, I. M. (2016). Likuiditas Sebagi Variabel Pemoderasi Pengaruh Profitabilitas Dan Struktur Modal Pada Return Saham Perusahaan Manufaktur. E-Jurnal Akuntansi Universitas Udayana, 407-432.

Oktoriana, M., \& Suharli, M. (2007). Hubungan Profitabilitas Dan Kebijakan Dividen Tunai Dengan Kecukupan Kas Dan Likuiditas Sebagai Moderating Variabel. Media Riset Akuntansi, Auditing, Dan Informasi, 141-162.

Pasadena, R. P. (2013). Pengaruh Likuiditas, Leverage, Profitabilitas Dan Ukuran Perusahan Terhadap Kebijakan Dividen Pada Perusahaan Manufaktur Yang Terdaftar Di Bursa Efek Indonesia (Skripsi). Jakarta: Fakultas Ekonomi dan Bisnis UIN Syarif Hidayatullah.

Permana, H. A. (2016). Analisis Pengaruh Leverage, Likuiditas, Profitabilitas, Pertumbuhan Perusahaan, dan Ukuran Perusahaan Terhadap Kebijakan Dividen Pada Perusahaan Manufaktur Yang Terdaftar Di BEI (Skripsi). Yogyakarta: Fakultas Ekonomi Universitas Negeri Yogyakarta.

Rahayu, A. S., \& Hari, M. (2016). Perngaruh Curent Ratio Dan Quick Ratio Terhadap Kebijakan Dividen Melalui Return on Equity Pada Perusahaan Manufaktur Yang Terdaftar BEI Tahun 2014. Jurnal Ekonomi dan Bisnis, 231-239.

Raissa, F. (2011). Faktor-Faktor Yang Mempengaruhi Kebijakan Dividen Pada Perusahaan Yang Tercatat Di Bursa Efek Indonesia (Jurnal). Surabaya: Universitas Katolik Widya Mandala Surabaya.

Sarmento , J. C., \& Dana, M. (2016). Pengaruh Return On Equity, Current Ratio, dan Earning Per Share Terhadap Kebijakan Dividen Pada Perusahaan Keuangan. E-Jurnal Manajemen Unud, V(7), 42244252.

Saleh, A. (2015). Pengaruh Rentabilitas Modal Sendiri, Solvabilitas, Profitabilitas, dan Likuiditas Terhadap Kebijakan Dividen Pada Perusahaan Manufaktur Yang Terdaftar Di Bursa Efek Indonesia Tahun 2011-2013. Jurnal FEKON, 1-16.

Setiawan, S. R. (2016, Maret 28). Keuangan. (J. Primus, Editor) Retrieved September 3, 2017, from Kompas: http://ekonomi.kompas.com/read/2016/03/28/160343826/Kin i.Pertumbuhan.Pangsa.Pasar.Investasi.Syariah.Lebih.Dominan.

Setyawan, R. A. (2014). Analisis Dampak Debt To Equity Ratio, Return On Equity, Return On Invesment, Firm Size, Dan Net Profit Margin Terhadap Kebijakan Dividen Kas Pada Sektor Keuangan Yang 
Anaz Bima Dewantara: Profitability and leverage, and the Implication

Tercatat di Bursa Efek Indonesia Periode 2009-2013. Semarang: Fakultas Ekonomi dan Bisnis Universitas Dian Nuswantoro .

Sjahrial, D. (2007). Manajemen Keuangan. Jakarta: Mitra Wacana Media.

Suharli, M. (2004). Pengaruh Profitability dan Investment Opportunity Set Terhadap Kebijakan Dividen Tunai dengan Likuiditas Sebagai Variabel Penguat (Studi pada Perusahaan yang Terdaftar di Bursa Efek Jakarta Periode 2002-2003). Jurusan Ekonomi Akuntansi, Fakultas Ekonomi - Universitas Kristen Petra, 9-16.

Susanti. (2016). Pengaruh Current Ratio (CR) Dan Return On Equity (ROE) Terhadap Return Saham Dengan Kebijakan Dividen Sebagai Variabel Intervening (Kasus Pada Perusahaan Manufaktur Yang Terdaftar Di BEI Tahun 2010-2014) (Skripsi). Yogyakarta: Fakultas Ekonomi Universitas Negeri Yogyakarta.

Sutrisno. (2012). Manajemen Keuangan Teori dan Konsep. Yogyakarta: Ekonisia.

Ulfah, A. (2015). Faktor-Faktor Yang Memepengaruhi Kebijakan Dividen dan Dampak Kebijakan Dividen Terhadap Stuktur Modal Bank BUMN. Jurnal Perbanas.

Ulfah, I. F. (2011). Pengaruh Agensi Cost, Firm Size, Dan Profitability Terhadap Kebijakan Dividen Dengan Likuiditas Sebagai Variabel Moderasi (Skripsi). Surakarta: Fakultas Ekonomi Universitas Sebelas Maret. 